\section{Growth dynamics and cyclin expression in cutaneous T-cell lymphoma cell lines}

\author{
Edyta Biskup,' Valentina Manfé,' \\ Maria R. Kamstrup, ${ }^{1}$ Robert Gniadecki ${ }^{1,2}$ \\ 'Department of Dermatology, Bispebjerg \\ Hospital, Copenhagen; \\ ${ }^{2}$ Faculty of Health Sciences, University of \\ Copenhagen, Denmark
}

\section{Abstract}

We have investigated cell growth dynamics and cyclins B1 and E expression in cell lines derived from mycosis fungoides (MyLa), Sézary syndrome (SeAx), and CD30+ lymphoproliferative diseases (Mac1, Mac2a, JK). Mac1 and Mac2a had the highest growth rate (doubling time 18-28 h, >90\% cycling cells) whereas SeAx was proliferating slowly (doubling time $55 \mathrm{~h}$, approximately $35 \%$ cycling cells). Expression of cyclin B1 correlated positively with doubling time whereas expression of cyclin $\mathrm{E}$ was unscheduled and constant across the investigated cell lines. All cell lines exhibited high expression of PCNA. Thus, we concluded that cyclin Bl could be used for rapid screening of cell proliferation in malignant lymphocytes derived from cutaneous Tcell lymphoma.

\section{Introduction}

Cutaneous T-cell lymphomas (CTCLs) belong to the extra-nodal lymphomas arising primarily in the skin. ${ }^{1}$ Common types of CTCLs (mycosis fungoides, Sézary's syndrome, and CD30+ lympho-proliferative diseases) are lowgrade neoplasias presenting a chronic, relapsing course. Curative treatments are not available, but CTCLs are responsive to ionizing radiation and PUVA (psoralen ultraviolet A therapy) in the early stages. Development of new medications for the advanced disease is hampered by a lack of suitable animal models, and cell lines have been used for the screening of new compounds. The most commonly used cell lines have been $\mathrm{MyLa}^{2}$ and $\mathrm{SeAx}^{3}$ derived from mycosis fungoides and Sézary syndrome, respectively, and Mac1, Mac2a, ${ }^{4}$ or $\mathrm{JK}^{5}$ obtained from patients with CD30+ lympho-proliferative diseases.

In this study we investigated growth dynamics and cell cycle characteristics in these cell lines. Particularly, we focused on the cell cycle distribution and expression of cyclins B1 and $\mathrm{E}$, which are the key regulators of proliferation via activation of the cyclin-dependent kinases. Cyclin expression takes place at specific and well-defined points of the cell cycle ${ }^{6}{ }^{6}$ however, in cancer cells unscheduled cyclin expression may be observed.

\section{Results and Discussion}

The proliferation rate of neoplastic cells often reflects their degree of malignancy. In this study we analyzed the growth dynamics of five CTCL cell lines and the expression pattern of cell cycle regulators.

The time required for cell population doubling differed significantly between cell lines tested (Figure 1), with Mac1 and Mac2a being the fastest growing cells (doubling time between 20 and $35 \mathrm{~h}$ ) and SeAx showing the slowest growth (between 40 and $80 \mathrm{~h}$ ). These observations were confirmed by BrdU incorporation analysis. After a 20-min pulse with 10 $\mu \mathrm{M}$ BrdU, we observed $>90 \%$ BrdU positive cells in the case of Mac1, Mac2a, and JK whereas only $40 \%$ in the case of MyLa and SeAx cell lines (Figure 1).

Cyclin B1 is an essential G2 cyclin necessary for CDK1 activation and cell entrance into the
Correspondence: Robert Gniadecki, Department of Dermatology D, Bispebjerg Hospital, Bispebjerg Bakke 23, DK-2400 Copenhagen, Denmark

E-mail: RGNI0001@bbh.regionh.dk

Key words: cutaneous lymhomas, cyclins, proliferation.

Received for publication: 25 March 2010. Accepted for publication: 31 March 2010.

This work is licensed under a Creative Commons Attribution 3.0 License (by-nc 3.0).

(C) Copyright E. Biskup et al., 2010

Licensee PAGEPress, Italy

Dermatology Reports 2010; 2:e8

doi:10.4081/dr.2010.e8

$\mathrm{M}$ phase. Its accumulation begins in the late $\mathrm{S}$ phase, reaches the maximal level as the cell enters mitosis, and is degraded rapidly at the beginning of anaphase. An altered expression pattern was observed in several neoplastic cell lines. For example, cyclin B1 has been detected in the G1 phase in HL-60 (leukemic), Hs578T, and T-47D (derived from breast carcinoma) cells. ${ }^{6}$ We did not observe this phenomenon in any of the cell lines we tested. The
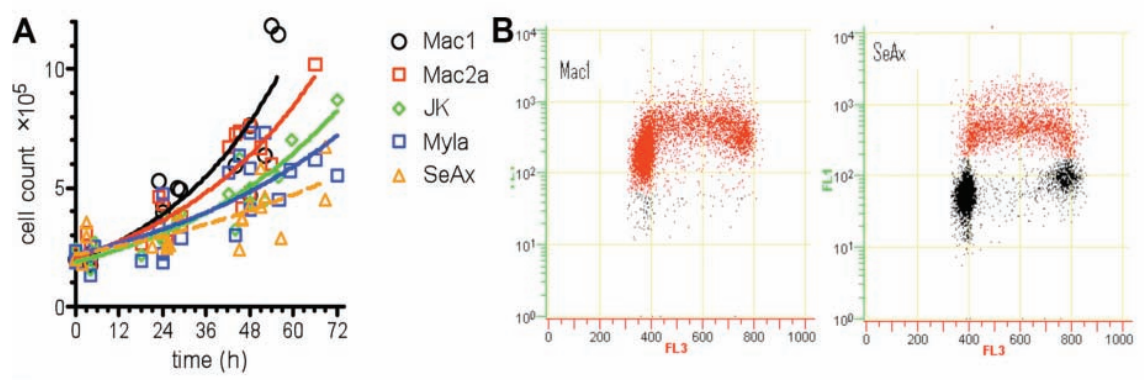

\begin{tabular}{|c|c|c|c|c|c|c|}
\hline & & Mac1 & Mac2a & JK & MyLa & $\operatorname{SeAx}$ \\
\hline $\begin{array}{l}\text { Cells per cell } \\
\text { cycle phase } \\
(\%)\end{array}$ & $\begin{array}{l}\mathrm{G} 0 / \mathrm{G} 1^{*} \\
\mathrm{~S}^{*} \\
\mathrm{G}^{*} \mathrm{M}^{*}\end{array}$ & $\begin{array}{c}59.2 \pm 7.7^{*} \\
14.4 \pm 4.0 \\
26.7 \pm 5.3\end{array}$ & $\begin{array}{l}56.9 \pm 7.6 \\
15.1 \pm 4.1 \\
28.1 \pm 5.3\end{array}$ & $\begin{array}{l}62.1 \pm 9.6 \\
15.8 \pm 4.3 \\
24.2 \pm 4.5\end{array}$ & $\begin{array}{c}54.3 \pm 13.3 \\
20.3 \pm 7.0 \\
25.8 \pm 7.4\end{array}$ & $\begin{array}{l}71.9 \pm 5.5 \\
14.1 \pm 5.2 \\
13.8 \pm 2.7\end{array}$ \\
\hline \multirow[t]{2}{*}{$\begin{array}{l}\text { Proliferation } \\
\text { rate }\end{array}$} & $\begin{array}{l}\text { Doubling time (hr) } \\
(95 \% \mathrm{Cl})^{\star \star}\end{array}$ & $\begin{array}{c}24,2 \\
(18.3-35.8)\end{array}$ & $\begin{array}{c}29,6 \\
(24.1-38.3)\end{array}$ & $\begin{array}{c}33,9 \\
(28.9-41.1)\end{array}$ & $\begin{array}{c}42,1 \\
(30.7-67.3)\end{array}$ & $\begin{array}{c}54,5 \\
(40.5-83.3)\end{array}$ \\
\hline & $\begin{array}{l}\text { BrdU } \\
\text { incorporation }(\%)^{*}\end{array}$ & $99.1 \pm 0.6$ & $99.3 \pm 0.5$ & $99.6 \pm 0.1$ & $38.7 \pm 4.0$ & $34.8 \pm 4.0$ \\
\hline
\end{tabular}

*mean with standard deviation

${ }^{* *}$ mean with $95 \%$ confidence intervals

Figure 1. Growth dynamics of cutaneous T-cell lymphoma cell lines. (A) Measurement of cell doubling time. Cells were seeded in the culture flasks at a density $2 \times 10^{5} / \mathrm{mL}$. Mac1, Mac2a and JK cells were grown in RPMI 1640 medium supplemented with $10 \%$ FCS; MyLa and SeAx cells were grown in GlutaMAX Dulbecco modified essential medium (DMEM) supplemented with $1 \mathrm{mM}$ L-glutamine and $10 \%$ FCS. Media, supplements, and serum were obtained from GIBCO BRL. Cell counting was performed twice daily by flow cytometry (Becton-Coulter) until the stationary phase was reached. The time required to double the cell population was calculated using GraphPad Prism (GraphPad Software, San Diego Ca, USA). (B) BrdU incorporation rate. Cells were pulsed for 20 min with 10 $\mu \mathrm{M}$ BrdU, fixed in ice-cold $70 \%$ ethanol for at least $20 \mathrm{hr}$, washed with PBS, and incubated in $2 \mathrm{~N} \mathrm{HCl}$ for 30 min prior to the addition of anti-BrdU mouse antibodies (Becton Dickinson). Goat anti-mouse antibodies labeled with Alexa-Fluor 488 (1:1000; Invitrogen) were applied as secondary antibodies. DNA was stained with 7-amino-actinomycin D (7AAD; Beckman Coulter). The percentage of BrdU positive cells was determined by flow cytometry analysis. BrdU incorporation rate (FL1) was plotted versus cellular DNA content (FL3). Quantification of flow cytometry data is provided in (C). 
cyclin B1 expression was perfectly scheduled, although the expression level differed among the cell lines tested and tended to be highest in the most rapidly proliferating cells (Figure 2 ). In contrast, the cyclin $\mathrm{E}$ pattern was similar in all cell lines. This factor is essential for cell entrance into the $\mathrm{S}$ phase, and therefore it is predominantly expressed in the G1 phase and decreases in the $\mathrm{S}$ and G2/M phases. However, we observed that a proportion of $\mathrm{S}$ and $\mathrm{G} 2 / \mathrm{M}$ cells remained cyclin E positive (Figure 2). This phenomenon represents unscheduled cyclin E expression and has been described before in leukemic cell lines, namely Jurkat, K562, and U937. ${ }^{8}$

PCNA, a subunit of DNA polymerase $\partial$, is a marker for growing cells. Its content increases in the late $\mathrm{Gl}$, peaks in the $\mathrm{S}$, and decreases in the G2/M phase. ${ }^{9}$ In the case of all CTCL cell lines tested, $>90 \%$ of cells were PCNA positive, regardless of the growth rate of the cells.

We concluded that the cyclin B1 expression is normal in CTCL cell lines and the level of expression roughly correlated with growth rate. In contrast, cyclin $\mathrm{E}$ expression is unscheduled and constant in the cell lines we tested. Furthermore, PCNA is not useful as a marker of proliferation rate.

\section{References}

1. Olsen E, Vonderheid E, Pimpinelli N, et al. Revisions to the staging and classification of mycosis fungoides and Sezary syndrome: a proposal of the International Society for Cutaneous Lymphomas (ISCL) and the cutaneous lymphoma task force of the European Organization of Research and Treatment of Cancer (EORTC). Blood 2007;110:1713-22.

2. Kaltoft K, Bisballe S, Dyrberg T, et al. Establishment of two continuous T-cell strains from a single plaque of a patient with mycosis fungoides. In Vitro Cell Dev Biol 1992;28A:161-7.

3. Kaltoft K, Bisballe S, Rasmussen HF, et al. A continuous T-cell line from a patient with Sezary syndrome. Arch Dermatol Res 1987;279:293-8.

4. Davis TH, Morton CC, Miller-Cassman R, et al. Hodgkin's disease, lymphomatoid papulosis, and cutaneous T-cell lymphoma derived from a common T-cell clone. $\mathrm{N}$

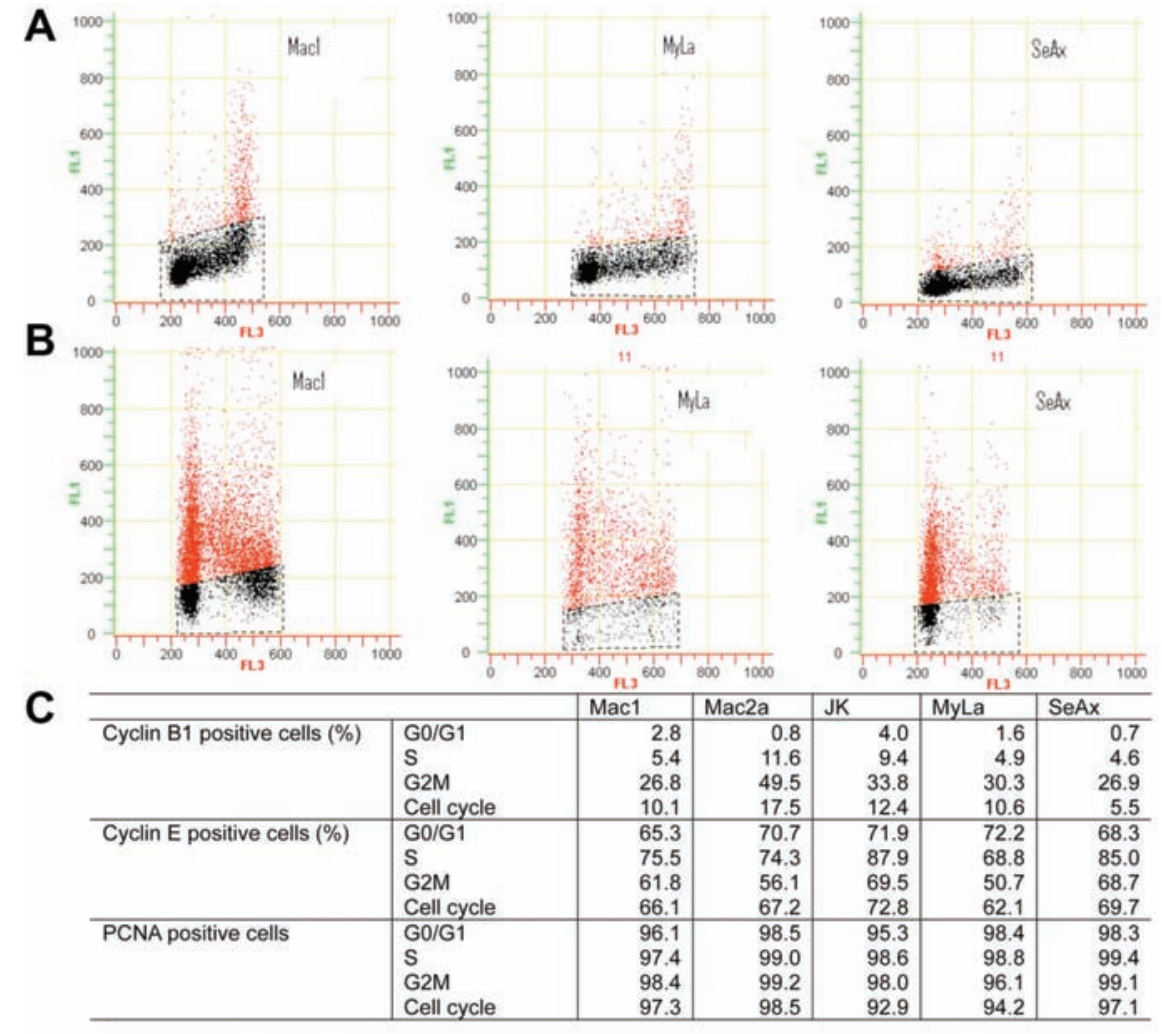

Figure 2. Cyclin B1 and cyclin E expression in cutaneous T-cell lymphoma cell lines. Cells $\left(2 \times 10^{\circ}\right)$ were washed in PBS and fixed in ice-cold $70 \%$ ethanol for at least $20 \mathrm{hr}$. Subsequently, cells were washed again, permeabilized using $0.25 \%$ Triton-X 100 (5 min) and stained using appropriate antibodies. In the case of cyclin B1 and PCNA staining, primary FITC labeled antibodies were used (diluted 1:50; BD Pharmingen ${ }^{\mathrm{TM}}$ ) for $2 \mathrm{hr}$. In the case of cyclin $\mathrm{E}$, cells were stained with primary mouse anti-human cyclin $\mathrm{E}$ antibodies (1:150; BD Pharmingen ${ }^{\mathrm{TM}}$ ) for $1 \mathrm{hr}$, followed by $1 \mathrm{hr}$ treatment with secondary goat anti-mouse antibodies labeled with Alexa-Fluor 488 (1:1000; Invitrogen). In all cases the appriopriate isotype control (for direct staining) or secondary control (for indirect staining) was used. DNA was stained with 7-amino-actinomycin D (7AAD; Beckman Coulter). Cellular fluorescence was measured using flow cytometer (Beckman Coulter). Total percentage of positive cells and percentage per cell cycle phase were calculated. Flow cytometry diagrams show cyclin B1 (A) and cyclin E (B) staining in Mac1, MyLa, and SeAx cells. Quantification of flow cytometry data is shown in (C).

Engl J Med 1992;326:1115-22.

5. Schiemann WP, Pfeifer WM, Levi E, et al. A deletion in the gene for transforming growth factor beta type I receptor abolishes growth regulation by transforming growth factor beta in a cutaneous T-cell lymphoma. Blood 1999;94:2854-61.

6. Darzynkiewicz Z, Gong J, Juan G, et al. Cytometry of cyclin proteins. Cytometry 1996;25:1-13.

7. Gong J, Ardelt B, Traganos F, et al. Unscheduled expression of cyclin $\mathrm{Bl}$ and cyclin E in several leukemic and solid tumor cell lines. Cancer Res 1994; 54: 4285-8.

8. Viallard JF, Lacombe F, Dupouy M, et al. Flow cytometry study of human cyclin B1 and cyclin E expression in leukemic cell lines: cell cycle kinetics and cell localization. Exp Cell Res 1999;247:208-19.

9. Kurki P, Vanderlaan M, Dolbeare F, et al. Expression of proliferating cell nuclear antigen (PCNA)/cyclin during the cell cycle. Exp Cell Res 1986;166:209-19. 